ISSN: 2036-5438

\title{
Sovereignty and Democracy: Overcoming Supranational Mutual Double-Binds from the Eurozone
}

by

Francesco Pigozzo*

Perspectives on Federalism, Vol. 8, issue 1, 2016 


\begin{abstract}
EU and EMU are facing a hastened phase of structural rather than episodic crisis, following the progressive shift of the world order from a bipolar toward a multi-polar system. From the sovereign debt trap to migratory pressures and security threats, all European crisis are intimately interdependent and long awaited rather than unexpected, since their origins trace back to a lack of reactivity of the European unification process to the progressive weakening of US hegemony in the world from 1971 onward. In this paper I point out that two double-binds mutually prevent a full (and widespread) understanding of Europe's situation and avoid for this reason a fully structural approach to the institutional reforming process in the EU: a 'sovereignty double-bind' and a 'democracy double-bind'. An effective roadmap toward political unification should primarily aim at tackling these misrepresentations instead of embracing them in the form of a gradualist approach to legitimacy issues.
\end{abstract}

Key-words

Eurozone, crisis, sovereignty, democracy, identity, double-binds 
Since the beginning of the sovereign debt crisis in Europe, following the 2007-2008 US financial crisis, European Council meetings took place at an unprecedented rate, alternating formal meetings with 'special', 'extraordinary' or 'Euro Area' ones. A total of fifty-seven (formal or informal) meetings were held between July 2008 and March 2016, with an average of around 7.6 meetings per year compared to 4.8 in the previous period (October 2000 - June 2008). As Carl Schmitt says: 'The exception is more interesting than the rule. The rule proves nothing; the exception proves everything.' (Schmitt 2005: 15). This exceptional series of summits perfectly matches the exceptional nature of the European crisis, where the monetary union and the entire European integration process seemed already 'gripped with an existential crisis that is slowly, but inexorably, destroying' (de Grauwe 2013) their very foundations before the migration crisis and other recent developments explicitly added new dimensions to the political puzzle. But while Heads of State and Government have clearly proved that Europe's sovereignty ultimately belongs to them, they could not yet give a sustainable and structural solution to financial, economic, social, security and political worries about Eurozone unity, the future of the European Union (EU, the Union) and its geopolitical role in the world. This is true despite the fact that, on the one hand, macroeconomic fundamentals of the Euro area as a whole are still considerably better than those of the United States (US), United Kingdom (UK) and Japan, and on the other hand, that the EU didn't exploit its enormous potential power yet in the fields of foreign, security and defence policies (besides, a single European defence would be extremely cost-effective, generating economies of scale and releasing resources for sustainable growth). What if today the 'state of exception' in Europe proved altogether the limits of intergovernmental methods in dealing with systemic crisis?

Eurostat's Selected Principal European Economic Indicators for March 2016 (Eurostat 2016) show that the Eurozone still runs significant current account and trade balance surpluses. A comparative assessment of some macroeconomic indicators over the period 2013-2017 confirms that both the EU and the Eurozone are in many cases in a better position than the US (see below, chart 1). The current crisis is actually envisaged as a financial and economic one, while its older and heavier institutional and political origins are still overlooked by the public debate and perniciously hidden behind its frightful economic 
and social consequences. Eight years after the crisis began, no serious economic recovery is in sight for either the Euro area or the EU in general - whose growth prospects, that were remarkably peculiar in 2013 world context (see below, chart 2), remain all in all weak (https://www.imf.org/external/pubs/ft/weo/2016/update/01/) despite the efforts of the European Central Bank and the Junker Commission.

The European Council's (EC) right to rule can be perceived as an unavoidable consequence of the EU's institutional architecture, but its strikingly ineffective results have nonetheless allowed its paradoxical meaning to emerge: Europe's public good is ultimately defined and interpreted by the less accountable and less supranational of its institutions. This is not just a curious crisis side effect. The EC's supremacy is at the core of the crisis itself, a sort of preliminary condition for the currency union's vulnerability. Ironically enough, the Lisbon Treaty signing and its entry into force cover the exact period from the Global Financial Crisis to the specific European emergency with the Greek debt crisis and scandal. That Treaty was supposed to close, for a long period, the permanent 'reforming process' dating back to the birth of the EU itself with the Maastricht Treaty. A few years and many failures later, the EC now has to acknowledge that deep Treaty changes are needed to structurally overcome the Eurozone crisis and save (making it 'genuine') the Economic and Monetary Union within the EU.

In this short paper, I draw on three main arguments against the mainstream approach to crisis management in Europe: firstly, I stress that this crisis is political rather than economic, both at the global and European level. The relevance of International Relations and power struggles to explain global monetary and financial instability today is largely underestimated. Secondly, I will point out that Europe as a whole is facing a hastened phase of a structural rather than episodic crisis, following the progressive shift of the world order from a bipolar toward a multi-polar system. Thirdly, I will stress that today's crisis in Europe has been long awaited rather than unexpected, since its origins trace back to a lack of reactivity of the European unification process to the progressive weakening of US hegemony in the world from 1971 onward.

I propose, on this basis, a significantly different criterion be used to draw a roadmap to genuinely achieve the European Monetary Union (EMU), as the roadmap included in the 'Five Presidents' Report' of June 2015 (Juncker 2015) will prove ineffective because it still relies on two double-binds that mutually prevent a full (and widespread) understanding of 
Europe's situation: the 'sovereignty double-bind', following which sovereignty is either legitimate (national level) or effective (Europe); and the 'democracy double-bind', for which democracy should be either diminished (for the sake of effectiveness) or restored (for the sake of legitimacy). Europe's agenda toward its political unification should primarily aim at tackling these misrepresentations instead of embracing them by means of a gradualist approach to legitimacy issues. One may observe that while Europe's ruling class is by now fully aware of the fact that only European unity can save (national) democracy, there is still a dangerous lack of awareness about the inverse relation: only (supranational) democracy can save European unity, since this long-term, structural crisis is by now taking new shapes that are only apparently unconnected and is rapidly eroding the pro-European consensus all over the continent. Little more than three years is left for the European ruling class to fully involve European citizens in the unification process and the next step of its institution-building — otherwise, the 2019 European elections are very likely to become a definitive rejection of European unity and of an unprecedented experiment to genuinely 'unite in diversity' human beings at a supranational level. What if the seventy year old constitutional method of Altiero Spinelli proved to be the right answer this time?

\section{A Political, Structural and Long Awaited Rather Than an Economic, Short-Term and Unexpected Crisis}

With a high unemployment rate in the Euro area (10.5\% in 2016, corresponding to almost 17 million unemployed people), it is by now generally acknowledged that the sovereign debt crisis, subsequent austerity measures in many countries of the Euro area and a persistent credit crunch - despite the European Central Bank's (ECB) extraordinary efforts to support the transmission of interest rate decisions to the economy and to inject liquidity into the real economy- resulted in deep economic and social downfall of the whole continent. But, as a logician would put it, this is nothing more than a 'joint effect' fallacy: both the sovereign debt and the subsequent social crisis are made possible in the Euro area, and would not be possible in any other monetary area in the world, by a distinguishing political and institutional factor. That is to say, to use Mario Draghi words, 'the political unsustainability of a Union in which the countries that pay and the countries 
that receive are always the same' or of a Union 'without a single Union government and economic policy' (Draghi 2013).

In other words, from a logical point of view, the public debate at all levels systematically reverses the cause-and-effect relation. It treats the crisis consequences as if they were its causes, very often completely overlooking the political side of the matter, like one could do with a minor detail or a taken-for-granted and unchangeable element of Europe's situation. That is why even the 'Five Presidents' Report' alone, despite its undeniable progress compared to the 'Four Presidents Report' (Van Rompuy 2012), cannot avoid mainstream public debates at national level to keep on quibblingly unbundling the problem in order to postpone and dilute the core measures it necessitates. Yes, this time the President of the Commission - the first one nominated following the European Elections results - coordinated the work; yes, he promoted a thorough discussion with Member States and part of the civil society; yes, he looked at last for the collaboration of the President of the European Parliament, who had been significantly overlooked by Herman Van Rompuy; and lastly yes, the document calls for a 'future euro area treasury accountable at the European level'. Nonetheless, it still applies to the 'Five Presidents' Report' what Roberto Castaldi wrote about the 'Four Presidents Report' (italics mine): 'The unbundling of problems may be instrumental to their solution, provided that their interaction and a vision of the whole structural solution is kept in mind.' (Castaldi 2012) The 'Five Presidents' Report' gives back supranational institutions a central role, but it falls short of the need to foster a debate on the 'vision of the whole structural solution'. This should be the role of the European Parliament and political groups. Despite its formal participation, the European Parliament will ultimately remain an object rather than a subject of reforming initiatives, in exactly the same way in which European citizens are regularly the object rather than the subject of the European integration process, until it will take a serious initiative on its own. Inter-institutional cooperation should not distract from the fact that the 'structural solution' for the euro area entails inter-institutional power struggles, since 'it does not seem possible to reconcile the institutional functioning of the EU with the principles of representative democracy except by a modification of the existing Treaties and the establishing of a European federal entity (not necessarily the presidential model of the US)' (Ponzano 2012). 
This fundamental weakness not only accounts for the structural inefficiency of any EU plan to achieve an admittedly fake monetary union and fully overcome a crisis that is expanding today to the free movement right, but also explains why the sovereign debt crisis itself could burst forth. Twenty-four years ago, European leaders were confronted with a difficult choice. Two ways were available to achieve an Economic and Monetary Union: let's name them 'convergence through mutual and communitarian supervision' and 'convergence through a unique fiscal and economic policy' (that is to say a European federal government). Convergence through mutual and communitarian supervision (CMCS) was the predictable choice of the Heads of State and Government: it allowed the EC to fulfil its core mission, which is well digested in the maxim 'making Europe run with the hares and hunt with the hounds'. The 'hares' are the two centuries old identities and institutions of national (self-styled 'sovereign') democracies; while the 'hounds' are the increasingly needed identity and institutions of a multilevel, supranational, fully accountable democracy. CMCS had the great advantage of further delaying the core political issues at stake since the birth of the first European community ${ }^{\mathrm{I}}$, but it could not completely get rid of them. It kept working as long as the world economic and monetary context was favourable enough to beguile public opinion about the effectiveness of such a system. The 2007-8 crisis simply unveiled some well-known truisms: the Euro does not rely on a genuine economic and monetary union; the Euro area has no Treasury and no momentous policies for true European growth and solidarity; lacking a political union, Europe cannot seriously tackle structural loss of technological and economic competitiveness nor can it save its welfare system short of a far-reaching continental plan to relaunch its development on a socially and environmentally sustainable basis. All of this was already evident before the current crisis, whose sole peculiarity is to finally enforce a sharp choice for the survival of the Euro.

'There is no national way out of the crisis. Expansionary measures are impossible at the level of Member States, which are obliged to choose fiscal consolidation as a priority; and in any case they would be domestically ineffective since most of the effects resulting from national measures would be lost through increased imports from other European countries. Therefore, every country will try to behave as a free rider, waiting 
for expansionary measures to be implemented by other Eurozone Member States, and stabilisation policy will prove sub-optimal' (Majocchi 2013).

Therefore, expansionary measures need to be truly European. In other words, this time the only possible way to overcome the crisis is to overtly grapple with the political and cultural problems that the evolution of the EMU toward a full federation inevitably brings about.

Long before today's emergency, it nonetheless had to be clear - at least since the 1970s and the end of the Bretton Woods system - that a sum of national behaviours does not equate a supranational behaviour, just like the sum of national public investments does not equate a European public investment: it is obviously a matter of economies of scale. The CMCS method is basically wasteful and unfit to fully develop Europe's potentialities. What inevitably becomes a problem, in front of an increasing number of compelling challenges simply incommensurable both with Nation-States and intergovernmental powers. Until the world order was guaranteed by a relatively stable system of continental states (the US and USSR, and the US alone after 1991), Europe could slowly upgrade to the economies of scale needed by an increasing global interdependence. The beginning of the XXI century has clearly shown that this stable framework has come to an end; the US alone cannot provide for a global order both in the security and economic domains. The Lehman Bros. collapse is symbolically akin to the collapse of the Twin Towers. A new multi-polar world is in the making, conflicts are less predictable, and global history has accelerated its rhythm. Europe must move faster towards the economies of scales it needs to actively take part in this history.

UN Climate Change conferences are a good example of the political and behavioural meaning of this concept, mostly applied by economists but generally relevant for the social sciences. Despite its strong and unanimously accepted negotiating position, the EU's bargaining power has been largely undermined by its institutional set-up; the UN Framework Convention on Climate Change does not benefit from any real European behaviour, but only from a sum of European national behaviours plus the participation of the Commission (Afionis 2009: 44). As a result, Europe is both weaker and more irresponsible than it should be in such a vital negotiation. The same applies to many other external contexts, but also to domestic ones. Let us take a less common example: Europe's 
linguistic diversity. Our persistent notion of irreducible national identities is strictly linked with linguistic diversities and the limits to mutual understanding. The EU is with reason ostensibly committed to the preservation and enhancement of this cultural richness (without ever giving up the necessity of preeminent working languages among national ones), just as the EC is committed to capitalizing on European unity (without ever giving up the ideal of preeminent national sovereignties). But is this the best way to preserve linguistic diversity as much as national sovereignties? Taking into account empirical evidence, the answer is clearly 'No'. Even in the Euro area, the English linguistic hegemony is pervasive more than ever, just as national sovereignties are steadily fading away wherever no European sovereignty is put in place to protect and fertilize them. Sooner or later, running with the hares and hunting with the hounds leaves you without both. If France had approved the European Defence and Political Community in 1954, the French language would probably still be alive at the international level today - with a concomitant political union, the monetary union would now allow for more divergences among national fiscal policies.

A supranational level of democratic government would perform much better for both the progressive and the conservative needs of the Europeans. For example, it would naturally and adequately boost the European economy through a plan for sustainable and smart development, thus creating a positive framework for national reforming processes. Likewise, it would more equitably address the need for a common linguistic tool that should not bestow any competitive advantage on particular groups of European citizens and that would not dare substitute or defeat natural languages in any social context.

These are the truths of which each new global crisis recurrently reminds us since the beginning of the European integration process. The difference with today's crisis is that it not only confronts European Nation-States with the one hundred year old alternative between: more (supranational) economies of scales or more rapid (national) declines? Today's specific crisis is at the same time political, long-awaited and structural, because a century after World War I it confronts Europe with the original dilemma: unite or perish, overcome national monisms and absolute divisions, or destroy your achievements. A century ago, Europe ultimately abdicated its historical responsibilities, violently stepping down from its leading role in the world system. Today, the Eurozone crisis endangers sixty 
years of communitarian (partial) achievements that have kept Europeans at least connected with global developments.

It is indeed clear that the single currency and the political goal of the European integration process will not survive without a genuine fiscal union. Such a union not only requires legitimacy, but it also entails: a totally different conception and practice of the European citizenship; and a new comprehensive approach to all the taboos of national sovereignties, namely the security, defence, and economic policies.

What are the main hurdles on the road toward the United States of Europe? One would instinctively reduce them to economic and/or political realities. Without entirely embracing a social constructivist credo, I want here to deal with the cultural hurdle which prevents European citizens and their ruling class from frankly facing up to their formerly long-term, by now immediate, interests.

\section{Double-Binds}

The building of European supranational institutions is traditionally interpreted as an injurious but sometimes necessary 'transfer of sovereignty' from the national to the European level. This is what I call the 'sovereignty double-bind', following which sovereignty is either legitimate (national level) or effective (Europe). But is this the only or best point of view from which to describe this process? As long as nationalist methodology is the undisputed reference frame of any scientific analysis, public debate and political approach to this question, the answer cannot be anything other than 'Yes'. Let's take global history as a frame of reference. There is no doubt in this case that European institutions mean a 'regain of sovereignty' for all European citizens, because their Nation-States and national societies are increasingly irrelevant in a world of continental states. From this perspective, the European integration process does no harm to national sovereignties, since they are doomed to disappear as long as they play at being self-sufficient in a globally interdependent world. A problem nonetheless remains, however: if European citizens are first of all national citizens of a single European Member State, is there any absolute reference frame, any solid criterion on which to conclusively base a profit and loss account of this process? 
The problem lies in the expression 'first of all'. Individuals do not in principle, and should not in practice, belong 'first of all' to any specific group, because they statutorily belong 'at the same time' to an infinite number of groups, otherwise they would not be 'individuals' at all, i.e. irreducible to each other. It has been a specific feature of nationalist paradigms to nurture the illusion of a privileged membership. Now, the fact that we cannot rationally identify any 'absolute' reference frame does not mean that we do not have the right to assess which frames are 'better' and which are 'worse' in relation to specific objectives and value scales. Nor does it mean that we can ignore the role of history (i.e. past individual and collective experiences) in the selection and institutionalization of belongings. But that is exactly what is at stake in the European integration process: a historical negation of absolute belongings and their institutions, a first applied example of institution-building led by bi-directional subsidiarity. Concerning sovereignty, we should therefore compare multiple frames with multiple objectives in order to establish step by step a sort of ideal chart. We shall then compare such a chart with a similar EU chart, describing the actual situation for European citizens. We would see that the 'sovereignty double-bind' is nothing more than a nationalist misunderstanding, which plays against the best sovereignty distribution from the point of view of individuals' reference frames. Any national citizen of any European Member State cannot generally hope to be 'sovereign' without the full development of institutions that enable him/her to act as a European; for example, he/she cannot specifically and satisfactorily self-determine his/her life in security and economic matters.

The 'sovereignty double-bind' relies on a 'democracy double-bind'. Nationalist methodology, a way of conceiving our social life as if there could be any absolute reference frame, has accustomed us to think of democracy as if it could fully or primarily develop one level of our territorial belongings. From this perspective, the European integration process inevitably means that democracy should be either diminished (for the sake of effectiveness) or restored at the national level (for the sake of legitimacy). Even the great innovation of an elected European Parliament in 1979, and its increasing number of powers and competences during its first forty years of life, could not break up this idea. With an inverse trend, the European elections turnout inexorably decreased over this period. Voters had their reasons. The Parliament has little or no competence in those matters which are traditionally considered an exclusive prerogative of national 
sovereignties, it even underuses the powers conferred by the Treaties and it shows little inclination to engage in an institutional conflict with the European Council's ineffectiveness in dealing with European crisis. But after 2014 European elections, with a turnout almost equal to 2009 and euroscepticism in the rise, pro-EU political groups in the Parliament seem to have understood that a new role for European citizens representatives is urgently needed in the debate about the future of the EMU and the EU: the Parliament must now come to grips with the difference between the EU and the Euro area governance issues while the AFCO committee is finally discussing how to employ the EP new powers in the Treaty reforming process.

Overcoming both double-binds I defined above is the main cultural challenge Europe must face if it is to survive its structural crisis: the Eurozone has naturally the biggest duties and interests from this point of view. Along with a fully bi-directional subsidiarity, a fully democratic system based on the division of powers is required at all institutional/territorial levels to guarantee effectiveness and legitimacy at the same time; in other words, that the best available means of empowering an individual's sovereignty in a globalized world have been put in place in the very continent that engendered the culture of absolute political divisions between human beings. This momentous shift in our traditional political paradigms cannot be divided into definite steps, nor can it be concealed under a plethora of technical solutions to short-term problems. It should explicitly inspire a genuine roadmap toward a European political union. A sound roadmap requires a shared view of its goals by the people who are supposed to draw and implement it. 
Chart 1 - Public deficit, debt, reserves and savings in Europe and the US (2013-2015 - forecasts for 2016-2017) - ratio of

GDP where not otherwise indicated

\begin{tabular}{|c|c|c|c|c|c|}
\hline & 2013 & 2014 & 2015 & 2016 & 2017 \\
\hline \multicolumn{6}{|c|}{ Net public lending (+) or borrowing (-) [EUR billions/GDP ratio] } \\
\hline EU & $-445.2 /-3.3$ & $-418.2 /-3$ & $-366.4 /-2.5$ & $-319.9 /-2.1$ & $-267.1 /-2.7$ \\
\hline Euro Area & $-294.4 /-3$ & $-260.9 /-2.6$ & $-225.3 /-2.2$ & $-208.4 /-1.9$ & $-177.2 /-1.6$ \\
\hline \multirow[t]{2}{*}{ USA } & $-664.1 /-5.3$ & $-634.0 /-4.9$ & $-676.6 /-4.2$ & $-750.9 /-4.3$ & $-792.1 /-4.4$ \\
\hline & Public debt & & & & \\
\hline EU & 87.2 & 88.6 & 87.2 & 86.9 & 85.7 \\
\hline Euro Area & 93.4 & 94.5 & 93.5 & 92.7 & 91.3 \\
\hline \multirow[t]{2}{*}{ USA } & 104.8 & 104.8 & 105.6 & 106.3 & 106.4 \\
\hline & \multicolumn{5}{|c|}{ Reserves (excluding gold - billions of US dollars) } \\
\hline Euro Area & 291 & 282 & & & \\
\hline \multirow[t]{2}{*}{ USA } & 133 & 119 & & & \\
\hline & \multicolumn{5}{|c|}{ Reserves (billions of US dollars) } \\
\hline Euro Area & 690 & 680 & & & \\
\hline \multirow[t]{2}{*}{ USA } & 448 & 434 & & & \\
\hline & \multicolumn{5}{|c|}{ Gross savings in the public sector } \\
\hline EU & 0.3 & 0.5 & 0.8 & 1 & 1.4 \\
\hline Euro Area & 0.6 & 0.9 & 1.1 & 1.1 & 1.4 \\
\hline USA & -2 & -1.7 & -0.9 & -0.9 & -0.9 \\
\hline
\end{tabular}




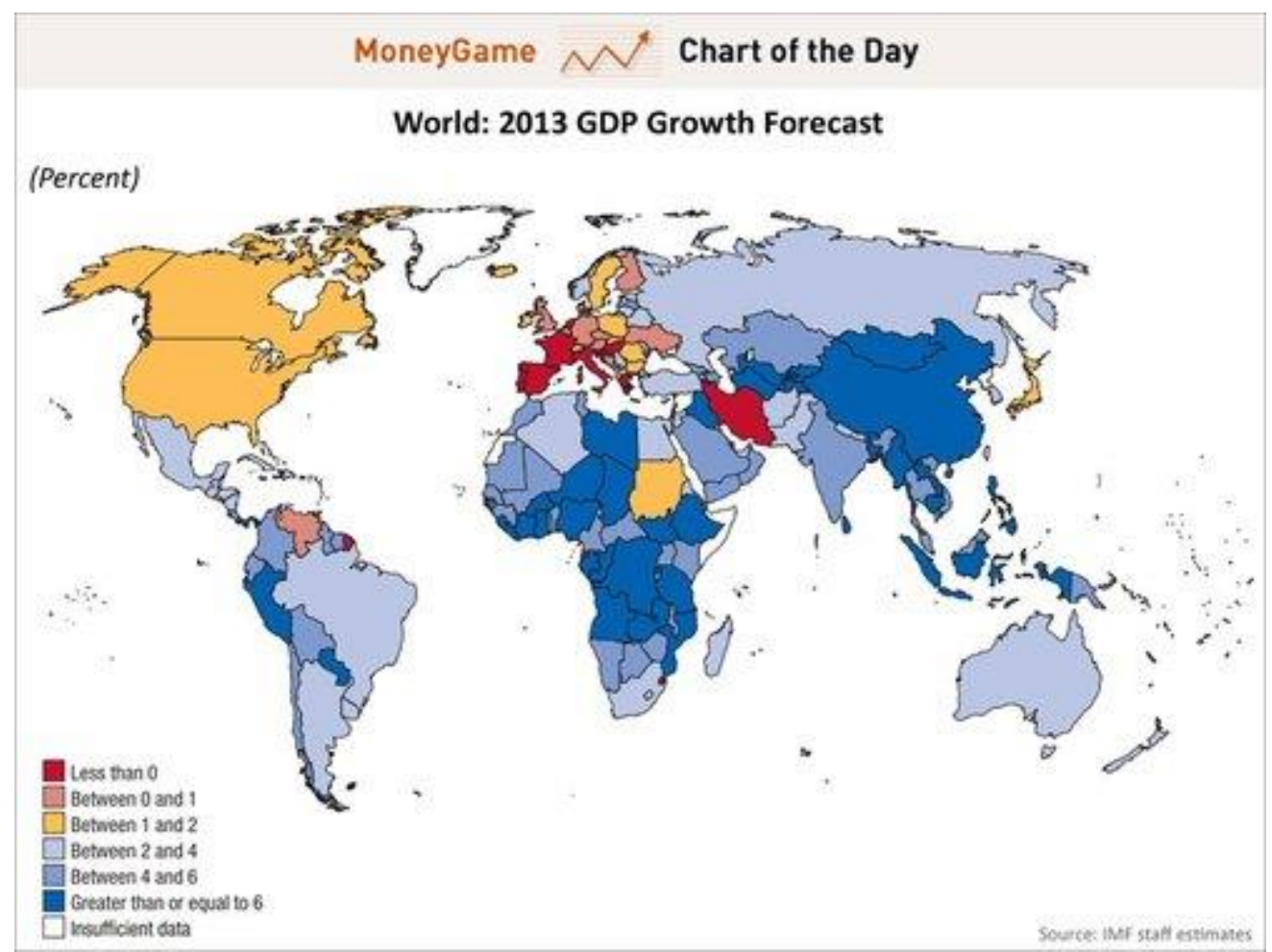

\footnotetext{
* Researcher, eCampus University; Affiliated Researcher, Scuola superiore Sant'Anna; Founder of CesUE (www.cesue.eu).

I One should never forget that the Schuman Declaration, which gave birth to the European Community of Coal and Steel, clearly stated: 'The pooling of coal and steel production should immediately provide for the setting up of common foundations for economic development as a first step in the federation of Europe.' (Schuman 1950).
}

\section{References}

- Afionis Stavros, 2009, 'European Union Coherence in UNFCCC Negotiations Under the New Treaty of Lisbon (Reform Treaty).' Sustainable Development Law \& Policy, IX(2): 43-47. Accessed March 18, 2016. http://digitalcommons.wcl.american.edu/sdlp/vol9/iss2/15/.

- $\quad$ Castaldi Roberto, 2012, 'The Dangers of Unbundling the Federal Union', in CSF Comments. Accessed March 18, 2016. http://gestione.csfederalismo.it/index.php/it/pubblicazioni/commenti?start=44.

- de Grauwe Paul, 2013, 'Debt Without Drowning.' Project Syndicate. Accessed March 18, 2016. http://www.project-syndicate.org/commentary/the-debt-pooling-scheme-that-the-eurozone-needs-by-paulde-grauwe.

- Draghi Mario, 2013, The Euro, Monetary Policy and Reforms, Speech on receiving an honorary degree in political science (Rome, May 6, 2013). Accessed March 18, 2016. http://www.ecb.int/press/key/date/2013/html/sp130506.en.html.

- $\quad$ Eurostat, 2016, 'Selected Principal European Economic Indicators'. Accessed March 18, 2016. http://epp.eurostat.ec.europa.eu/portal/page/portal/euroindicators/peeis. 


\begin{tabular}{lllllll}
\hline IMF, 'World & Economic & Outlook.'. & Accessed & March & 18, & 2016.
\end{tabular}
http://www.imf.org/external/pubs/ft/weo/2013/01/c2/fig2 1.pdf.

- Juncker Jean-Claude, 2015, (in close cooperation with Donald Tusk, Jeroen Djsselbloem, Mario Draghi and Martin Schulz), Completing Europe's Economic and Monetary Union, accessed March 18, 2016, http://ec.europa.eu/priorities/sites/beta-political/files/5-presidents-report en.pdf.

- Majocchi Alberto, 2013, Priority: the European Fund for Growth and Employment, CSF Comments Accessed March 18, 2016. http://gestione.csfederalismo.it/index.php/it/pubblicazioni/commenti?start=33.

- Ponzano Paolo, 2012, Democracy and European Governance, CSF Discussion Papers. Accessed March 18, 2016. $\quad$ http://www.csfederalismo.it/en/publications/policy-paper/1002-democracy-and-europeangovernance.

- Schmitt Carl, 2005, Political Theology. Four Chapters on the Concept of Sovereignty, trans. by George Schwab, University of Chicago Press, Chicago.

- Schuman Robert, 1950, 'Declaration of 9 may.' Foundation Robert Schuman. Accessed March 18, 2016. http://www.robert-schuman.eu/en/declaration-of-9-may-1950.

- Van Rompuy Herman, 2012 (in collaboration with José Manuel Barroso, Jean-Claude Juncker and Mario Draghi), Towards a genuine economic and monetary union. Accessed March 18, 2016. http://ec.europa.eu/economy finance/focuson/crisis/documents/131201 en.pdf. 